\title{
On Gluconeogenesis of Human Liver
}

\author{
Accelerated Hepatic Glucose Formation Induced by Increased Precursor Supply* ** \\ G. Dietze, M. Wicklmayr, K. D. Hepp, W. Bogner, H. Mehnert, H. Czempiel and H. G. Henftling \\ 3rd Medical Department, the Diabetes Research Unit and the Department of Nuclear Medicine, Schwabing City Hospital, Munich, Federal \\ Republic of Germany
}

Summary. In 8 subjects in whom portal vein catheters had been inserted 5-6 days previously during cholecystectomy, arterial and portal concentrations of glucose, lactate, pyruvate, glycerol, alanine, free fatty acids, $\beta$-hydroxybutyrate and acetoacetate revealed no significant differences. This provided the basis for the calculation of hepatic balances from arterio-hepatic venous substrate-differences in 17 healthy volunteers. In eight of them metabolic balances were determined during elevated hepatic lactate supply. Kinetics of the substrates throughout the whole test period in 9 controls showed no gross interference from the catheterization or infusion procedure. The elevated hepatic lactate concentration caused a doubling of hepatic glucose output, which could almost entirely be accounted for by a fivefold increase of hepatic lactate uptake. This acceleration of hepatic gluconeogenesis was accompanied by a significant increment of hepatic free fatty acid uptake, whereas hepatic ketone body production did not change. These data seem to support the view that hepatic energy requirements caused by an accelerated gluconeogenesis might be covered from enhanced free fatty acid oxidation.

Key words: Arterial, portal, hepatic-venous substrate concentrations, hepatic blood flow, intravenous lactate infusion, hepatic gluconeogenesis, hepatic free fatty acid uptake, hepatic ketogenesis.

When the liver of a fasted rat is perfused with lactate, pyruvate, glycerol and alanine individually at physiological concentrations, the sum of their glucose-

\footnotetext{
* Supported by a grant from Sonderforschungsbereich 51 of the Deutsche Forschungsgemeinschaft

** Part of this work has been presented in preliminary form at the 8th Annual Meeting of the European Society for the Study of Diabetes
}

production rates is almost identical with the value of this rate obtained by a mixture of the same substrates [1]. This additive effect demonstrates that no step in the gluconeogenic pathway is near saturation at physiological substrate concentrations. This could result in a severalfold increase in the rate of hepatic glucose formation when lactate concentration rises, i. e. during severe muscular exercise. Since acceleration of glucose utilization by the exercising muscle imposes a considerable drain on blood glucose [2], glucose homeostasis could not be maintained, if lactate were not produced at a very high rate and could not rapidly be reconverted into glucose. The demonstration of a faster de novo glucose-synthesis due to an individual increase of lactate in the present study underlines the importance of the precursor concentration per se for the control of gluconeogenesis.

\section{Materials and Methods}

\section{Subjects}

17 subjects were recruited from medical students. Their average age was $26.5 \pm 0.6$ years, their height $175.3 \pm 0.8 \mathrm{~cm}$ and their weight $70.9 \pm 1.0 \mathrm{~kg}$ (expected weight range: $64.2-70.6$ [3]). Physical examination as well as laboratory tests excluded internal diseases. Particularly, liver function tests and postprandial serum glucose levels were normal. In 8 patients who underwent cholecystectomy an additional liver biopsy proved the absence of gross hepatic disease. The average age of this group was $31.3 \pm 1.9$ years, their height $175.1 \pm 1.9 \mathrm{~cm}$ and their weight $67.5 \pm 2.7 \mathrm{~kg}$ (expected weight range $64.2-70.6$ [3]). The normal subjects received no drugs especially no premedication. This was also true for the patients who underwent the test 5-6 days after the operation. 
Table 1. Arterial and portal substrate concentrations ${ }^{a}$

\begin{tabular}{lll}
\hline & Arterial & Portal \\
\hline Glucose & $4.28 \pm 0.21$ & $4.29 \pm 0.21$ \\
Lactate & $0.59 \pm 0.10$ & $0.60 \pm 0.10$ \\
Pyruvate & $0.048 \pm 0.008$ & $0.047 \pm 0.006$ \\
Alanine & $0.145 \pm 0.021$ & $0.146 \pm 0.021$ \\
Glycerol & $0.073 \pm 0.011$ & $0.075 \pm 0.011$ \\
Free fatty acids & $0.459 \pm 0.079$ & $0.451 \pm 0.073$ \\
B-Hydroxybutyrate & $0.113 \pm 0.024$ & $0.127 \pm 0.023$ \\
Acetoacetate & $0.061 \pm 0.008$ & $0.062 \pm 0.007$ \\
\hline
\end{tabular}

${ }^{\text {a }}$ Mean \pm SEM of 4 blood samples in mmoles $/ 1$ from 8 patients $5-6$ days after cholecystectomy in the postabsorptive state $(15 \mathrm{~h}$ fasting)

Table 2. Effect of catheterization and infusion procedure on hepatic blood flow (HBF) and hepatic uptake of substrates ${ }^{\mathrm{b}}$

\begin{tabular}{lrrr}
\hline & Basal period & \multicolumn{2}{c}{ Saline Infusion } \\
\hline HBF $^{\mathrm{a}}$ & $77.1 \pm 1.5$ & $75.8 \pm 1.7$ & $76.3 \pm 1.4$ \\
Glucose $^{\mathrm{b}}$ & $-45.3 \pm 5.8$ & $-49.6 \pm 5.2$ & $-51.8 \pm 5.7$ \\
Lactate & $12.9 \pm 1.3$ & $13.4 \pm 1.7$ & $11.8 \pm 1.5$ \\
Pyruvate & $1.0 \pm 0.2$ & $1.0 \pm 0.2$ & $0.8 \pm 0.2$ \\
Alanine & $3.9 \pm 0.8$ & $3.3 \pm 0.8$ & $3.6 \pm 0.6$ \\
Glycerol & $4.3 \pm 0.5$ & $4.2 \pm 0.6$ & $4.1 \pm 0.5$ \\
Free fatty acids & $10.6 \pm 2.7$ & $9.2 \pm 1.8$ & $10.7 \pm 2.0$ \\
R-Hydroxybutyrate & $-9.0 \pm 2.4$ & $-9.9 \pm 2.0$ & $-12.8 \pm 2.6$ \\
Acetoacetate & $-6.6 \pm 1.0$ & $-6.2 \pm 0.8$ & $-6.0 \pm 0.9$ \\
\hline
\end{tabular}

The values represent the mean \pm SEM of 9 volunteers in $\mathrm{ml} / 100 \mathrm{~g}$ of liver weight $\times \min ^{\mathrm{a}}$ and $\mu$ moles $/ 100 \mathrm{~g} \times \min ^{\mathrm{b}}$. Calculation of the balances was performed within $30 \mathrm{~min}$ of a basal period and within $10-20 \mathrm{~min}$ and $50-60 \mathrm{~min}$ after the start of the saline infusion. For details see Materials and Methods

\section{Procedure}

In the 8 patients catheterization of the portal vein was performed via the umbilical vein during cholecystectomy according to previously described techniques [4]. 5-6 days after the operation and in the postabsorptive state ( $15 \mathrm{~h}$ fasting) simultaneous blood samples from the femoral artery and the portal vein were collected for the determination of substrates at $10 \mathrm{~min}$ intervals for a period of $30 \mathrm{~min}$ (Table 1 ) and in one case during $40 \mathrm{~min}$ of an intravenous lactate infusion $\left(0.03 \mathrm{mmoles} \cdot \mathrm{kg}^{-1} \cdot \mathrm{min}^{-1}\right)$ into an antecubital vein.

In the 17 volunteers, after an overnight fast $(15 \mathrm{~h})$, a woven dacron Goodale-Lubin catheter (type $125 \mathrm{c}$, size $7 \mathrm{~F}$, US Catheter and Instrument Corporation, Glenforce, New York, USA) was placed from an antecubital vein into the right hepatic vein under fluoroscopic control. Arterial blood was drawn through a Seldinger cannula (size PE 160, Kifa, Sweden) from the right femoral artery. Patency was maintained by an infusion of 0.1 unit per $\mathrm{kg}$ body weight per minute of heparin in $0.9 \% \mathrm{NaCl}(1 \mathrm{ml} / \mathrm{min})$. This rate guarantees no significant effect on lipoproteinlipase activity and consequently on free fatty acid levels [5]. In the 17 subjects, at 10 min intervals arterial and hepatic venous blood samples were collected simultaneously throughout a $30 \mathrm{~min}$ basal period for chemical analysis. Then, in 8 of them a sodium lactate solution ( $150 \mathrm{mmoles} / 1)$ was infused into an antecubital vein at a rate of 0.03 mmoles $\cdot \mathrm{kg}^{-1} \cdot \mathrm{min}^{-1}$ and additional blood samples were obtained at $10 \mathrm{~min}$ intervals for $40 \mathrm{~min}$ (Table 3). During the same test period 9 of them received the same volume as physiological saline (Table 2). Total blood loss was less than $200 \mathrm{ml}$ in normal volunteers and less than $100 \mathrm{ml}$ in patients.

During the basal period and the infusion of lactate or saline, hepatic blood flow (HBF) was measured. Since conventional dye clearance as a technique for the measurement of hepatic blood flow could not be used without risk [6] and dye excretion may be impaired when hepatic metabolism was altered, i. e. during fructose infusion [7], a gas exchange technique was employed which had been used successfully before $[8,9,10]$ and could be assumed to remain valid during lactate infusion [11]. The tracer ${ }^{133}$ xenon was given by inhalation for $6 \mathrm{~min}$ in a closed circuit system containing an oxygen: ${ }^{133}$ xenon-mixture $(500 \mu \mathrm{Ci}$ ${ }^{133}$ xenon $/ 1 \mathrm{O}_{2}$ ). With the help of a valve the volunteer was then switched to room air and the exhaled ${ }^{133} \mathrm{xe}$ non passed through a hose into the open air (desaturation). The exhaled carbon dioxide was trapped by an absorber. During the following $20 \mathrm{~min}$ the washout of ${ }^{133}$ xenon from the liver was recorded by a sodium iodide crystal $\left(1^{3 / 4} \times 2\right.$ inch $)$. This washout was analyzed on the basis of the rules for the measurement of blood flow with radioactive labelled gases developed by Kety [11] and by Morales and Smith [12]. Accordingly, recirculation could either be handled by an analog computer [9] or by a graphical analysis [10]. This procedure yielded a monoexponential washout process, the constant $\mathrm{K}$ of which could be considered to be directly proportional to the hepatic perfusion $\mathrm{F}$ and indirectly to the partition coefficient $\lambda$ of ${ }^{133}$ xenon $(\mathrm{F}=\mathrm{k} \cdot \lambda)$, which had been found to be 0.74 [13]. Precision of the method was proven by 20 serial determinations revealing a standard deviation of $3.5 \%$.

\section{Analysis}

Blood glucose $(0.31 \%)^{1}$, lactate $(0.56 \%)$, pyruvate $(0.75 \%)$, alanine $(0.97 \%)$, glycerol $(1,29 \%), \beta$-hydroxybutyrate $(1.43 \%)$ and acetoacetate $(2.0 \%)$ were determined enzymatically [14-20], the plasma free

\footnotetext{
1 SEM of ten repeated meisurements
} 
Table 3. Hepatic blood flow $(\mathrm{HBF})^{\mathrm{a}}$, arterial concentration $(\mathrm{A})^{\mathrm{b}}$, hepatic extraction $(\mathrm{A}-\mathrm{HV})^{\mathrm{b}}$ and hepatic uptake (UTIL) ${ }^{\mathrm{c}}$ of substrates during lactate infusion

\begin{tabular}{|c|c|c|c|c|c|c|c|c|c|}
\hline & & \multicolumn{4}{|l|}{ Basal } & \multicolumn{4}{|c|}{ Lactate infusion } \\
\hline & & $-30 \min$ & $-20 \min$ & $-10 \min$ & $0 \mathrm{~min}$ & $10 \mathrm{~min}$ & $20 \mathrm{~min}$ & $30 \mathrm{~min}$ & $40 \mathrm{~min}$ \\
\hline $\mathrm{HBF}^{\circ}$ & & \multicolumn{4}{|c|}{$78.1 \pm 3.3$} & \multicolumn{4}{|c|}{$107.0 \pm 3.0^{d}$} \\
\hline \multirow[t]{3}{*}{ Glucose } & $A^{b}$ & $\begin{array}{r}4.43 \\
\pm 0.20\end{array}$ & $\begin{array}{r}4.53 \\
\pm 0.21\end{array}$ & $\begin{array}{r}4.52 \\
\pm 0.20\end{array}$ & $\begin{array}{r}4.44 \\
\pm 0.18\end{array}$ & $\begin{array}{r}4.47 \\
\pm 0.19\end{array}$ & $\begin{array}{r}4.49 \\
\pm 0.14\end{array}$ & $\begin{array}{r}4.55 \\
\pm 0.22\end{array}$ & $\begin{array}{r}4.71 \\
\pm 0.17\end{array}$ \\
\hline & $\mathrm{A}-\mathrm{HV}^{\mathrm{b}}$ & $\begin{array}{l}-0.64 \\
\pm 0.11\end{array}$ & $\begin{array}{l}-0.52 \\
\pm 0.09\end{array}$ & $\begin{array}{l}-0.57 \\
\pm 0.05\end{array}$ & $\begin{array}{l}-0.62 \\
\pm 0.05\end{array}$ & $\begin{array}{l}-0.96^{d} \\
\pm 0.10\end{array}$ & $\begin{array}{l}-0.84^{\mathrm{d}} \\
\pm 0.09\end{array}$ & $\begin{array}{l}-0.84^{\mathrm{d}} \\
\pm 0.06\end{array}$ & $\begin{array}{l}-0.84^{\mathrm{d}} \\
\pm 0.10\end{array}$ \\
\hline & UTIL $^{c}$ & \multicolumn{4}{|c|}{$-42.1 \pm 4.6$} & \multicolumn{4}{|c|}{$-89.8 \pm 7.5^{\mathrm{d}}$} \\
\hline \multirow[t]{3}{*}{ Lactate } & A & $\begin{array}{r}0.47 \\
\pm 0.07\end{array}$ & $\begin{array}{r}0.44 \\
\pm 0.05\end{array}$ & $\begin{array}{r}0.43 \\
\pm 0.05\end{array}$ & $\begin{array}{r}0.43 \\
\pm 0.05\end{array}$ & $\begin{array}{r}0.90^{\mathrm{d}} \\
\pm 0.08\end{array}$ & $\begin{array}{r}1.16^{\mathrm{d}} \\
\pm 0.13\end{array}$ & $\begin{array}{r}1.24^{\mathrm{d}} \\
\pm 0.10\end{array}$ & $\begin{array}{r}1.38^{\mathrm{d}} \\
\pm 0.10\end{array}$ \\
\hline & A-HV & $\begin{array}{r}0.08 \\
\pm 0.01\end{array}$ & $\begin{array}{r}0.12 \\
\pm 0.01\end{array}$ & $\begin{array}{r}0.11 \\
\pm 0.01\end{array}$ & $\begin{array}{r}0.13 \\
\pm 0.02\end{array}$ & $\begin{array}{ll} & 0.37^{\mathrm{d}} \\
\pm & 0.06\end{array}$ & $\begin{array}{c}0.47^{\mathrm{d}} \\
\pm 0.07\end{array}$ & $\begin{array}{c}0.49^{\mathrm{d}} \\
\pm 0.04\end{array}$ & $\begin{array}{c}0.55^{\mathrm{d}} \\
\pm 0.05\end{array}$ \\
\hline & UTIL & \multicolumn{4}{|c|}{$9.1 \pm 1.2$} & \multicolumn{4}{|c|}{$51.7 \pm 5.8^{\mathrm{d}}$} \\
\hline \multirow[t]{3}{*}{ Pyruvate } & A & $\begin{array}{r}0.037 \\
\pm 0.003\end{array}$ & $\begin{array}{r}0.035 \\
\pm 0.003\end{array}$ & $\begin{array}{r}0.035 \\
\pm 0.003\end{array}$ & $\begin{array}{r}0.035 \\
\pm 0.003\end{array}$ & $\begin{array}{c}0.043^{d} \\
\pm 0.003\end{array}$ & $\begin{array}{r}0.053^{d} \\
\pm 0.006\end{array}$ & $\begin{array}{r}0.053^{\mathrm{d}} \\
\pm 0.007\end{array}$ & $\begin{array}{r}0.052^{d} \\
\pm 0.007\end{array}$ \\
\hline & A-HV & $\begin{array}{r}0.010 \\
\pm 0.002\end{array}$ & $\begin{array}{r}0.006 \\
\pm 0.002\end{array}$ & $\begin{array}{r}0.007 \\
\pm 0.001\end{array}$ & $\begin{array}{r}0.008 \\
\pm 0.002\end{array}$ & $\begin{array}{r}0.008 \\
\pm 0.003\end{array}$ & $\begin{array}{r}0.008 \\
\pm 0.004\end{array}$ & $\begin{array}{r}0.008 \\
\pm 0.006\end{array}$ & $\begin{array}{r}0.005 \\
\pm 0.006\end{array}$ \\
\hline & UTIL & \multicolumn{4}{|c|}{$0.7 \pm 0.1$} & \multicolumn{4}{|c|}{$0.8 \pm 0.5$} \\
\hline \multirow[t]{3}{*}{ Alanine } & A & $\begin{array}{r}0.157 \\
\pm 0.014\end{array}$ & $\begin{array}{r}0.155 \\
\pm 0.017\end{array}$ & $\begin{array}{r}0.147 \\
\pm 0.017\end{array}$ & $\begin{array}{r}0.152 \\
\pm 0.021\end{array}$ & $\begin{array}{r}0.147 \\
\pm 0.016\end{array}$ & $\begin{array}{r}0.150 \\
\pm 0.014\end{array}$ & $\begin{array}{r}0.157 \\
\pm 0.016\end{array}$ & $\begin{array}{r}0.149 \\
\pm 0.014\end{array}$ \\
\hline & A-HV & $\begin{array}{r}0.046 \\
\pm 0.007\end{array}$ & $\begin{array}{r}0.045 \\
\pm 0.010\end{array}$ & $\begin{array}{r}0.039 \\
\pm 0.006\end{array}$ & $\begin{array}{r}0.053 \\
\pm 0.012\end{array}$ & $\begin{array}{r}0.046 \\
\pm 0.008\end{array}$ & $\begin{array}{r}0.044 \\
\pm 0.013\end{array}$ & $\begin{array}{r}0.043 \\
\pm 0.012\end{array}$ & $\begin{array}{r}0.033 \\
\pm 0.010\end{array}$ \\
\hline & UTIL & \multicolumn{4}{|c|}{$3.4 \pm 0.8$} & \multicolumn{4}{|c|}{$4.9 \pm 1.5$} \\
\hline \multirow[t]{3}{*}{ Glycerol } & A & $\begin{array}{r}0.064 \\
\pm 0.006\end{array}$ & $\begin{array}{r}0.061 \\
\pm 0.007\end{array}$ & $\begin{array}{r}0.060 \\
\pm 0.005\end{array}$ & $\begin{array}{r}0.074 \\
\pm 0.009\end{array}$ & $\begin{array}{r}0.079 \\
\pm 0.007\end{array}$ & $\begin{array}{r}0.071 \\
\pm 0.009\end{array}$ & $\begin{array}{r}0.073 \\
\pm 0.005\end{array}$ & $\begin{array}{r}0.073 \\
\pm 0.007\end{array}$ \\
\hline & A-HV & $\begin{array}{r}0.044 \\
\pm 0.004\end{array}$ & $\begin{array}{r}0.038 \\
\pm 0.006\end{array}$ & $\begin{array}{r}0.040 \\
\pm 0.005\end{array}$ & $\begin{array}{r}0.053 \\
\pm 0.008\end{array}$ & $\begin{array}{r}0.053 \\
\pm 0.009\end{array}$ & $\begin{array}{r}0.050 \\
\pm 0.008\end{array}$ & $\begin{array}{r}0.050 \\
\pm 0.006\end{array}$ & $\begin{array}{r}0.051 \\
\pm 0.007\end{array}$ \\
\hline & UTIL & \multicolumn{4}{|c|}{$3.6 \pm 0.5$} & \multicolumn{4}{|c|}{$5.4 \pm 0.6^{\mathrm{d}}$} \\
\hline \multirow[t]{3}{*}{ Free fatty acids } & A & $\begin{array}{r}0.498 \\
\pm 0.051\end{array}$ & $\begin{array}{r}0.492 \\
\pm 0.050\end{array}$ & $\begin{array}{r}0.469 \\
\pm 0.048\end{array}$ & $\begin{array}{r}0.470 \\
\pm 0.042\end{array}$ & $\begin{array}{r}0.498 \\
\pm 0.046\end{array}$ & $\begin{array}{r}0.529 \\
\pm 0.045\end{array}$ & $\begin{array}{r}0.554 \\
\pm 0.055\end{array}$ & $\begin{array}{r}0.565 \\
\pm 0.062\end{array}$ \\
\hline & A-HV & $\begin{array}{r}0.107 \\
\pm 0.024\end{array}$ & $\begin{array}{r}0.114 \\
\pm 0.017\end{array}$ & $\begin{array}{r}0.093 \\
\pm 0.020\end{array}$ & $\begin{array}{r}0.108 \\
\pm 0.021\end{array}$ & $\begin{array}{r}0.098 \\
\pm 0.013\end{array}$ & $\begin{array}{r}0.118 \\
\pm 0.020\end{array}$ & $\begin{array}{r}0.120 \\
\pm 0.022\end{array}$ & $\begin{array}{r}0.126 \\
\pm 0.028\end{array}$ \\
\hline & UTIL & \multicolumn{4}{|c|}{$8.7 \pm 1.6$} & \multicolumn{4}{|c|}{$12.6 \pm 2.2^{\mathrm{d}}$} \\
\hline \multirow[t]{3}{*}{$\beta$-Hydroxybutyrate } & A & $\begin{array}{r}0.126 \\
\pm 0.017\end{array}$ & $\begin{array}{r}0.133 \\
\pm 0.014\end{array}$ & $\begin{array}{r}0.163 \\
\pm 0.019\end{array}$ & $\begin{array}{r}0.176 \\
\pm 0.021\end{array}$ & $\begin{array}{r}0.170 \\
\pm 0.025\end{array}$ & $\begin{array}{r}0.161 \\
\pm 0.017\end{array}$ & $\begin{array}{r}0.158 \\
\pm 0.024\end{array}$ & $\begin{array}{r}0.131 \\
\pm 0.021\end{array}$ \\
\hline & A-HV & $\begin{array}{l}-0.110 \\
\pm 0.022\end{array}$ & $\begin{array}{l}-0.123 \\
\pm 0.031\end{array}$ & $\begin{array}{l}-0.100 \\
\pm 0.026\end{array}$ & $\begin{array}{l}-0.107 \\
\pm 0.018\end{array}$ & $\begin{array}{l}-0.081 \\
\pm 0.014\end{array}$ & $\begin{array}{l}-0.055 \\
\pm 0.022\end{array}$ & $\begin{array}{l}-0.048 \\
\pm 0.017\end{array}$ & $\begin{array}{l}-0.068 \\
\pm 0.021\end{array}$ \\
\hline & UTIL & \multicolumn{4}{|c|}{$-7.8 \pm 1.9$} & \multicolumn{4}{|c|}{$-5.3 \pm 1.4$} \\
\hline \multirow[t]{3}{*}{ Acetoacetate } & A & $\begin{array}{r}0.080 \\
\pm 0.012\end{array}$ & $\begin{array}{r}0.084 \\
\pm 0.012\end{array}$ & $\begin{array}{r}0.096 \\
\pm 0.015\end{array}$ & $\begin{array}{r}0.095 \\
\pm 0.013\end{array}$ & $\begin{array}{r}0.097 \\
\pm 0.013\end{array}$ & $\begin{array}{r}0.091 \\
\pm 0.013\end{array}$ & $\begin{array}{r}0.087 \\
\pm 0.013\end{array}$ & $\begin{array}{r}0.064 \\
\pm 0.014\end{array}$ \\
\hline & A-HV & $\begin{array}{l}-0.071 \\
\pm 0.010\end{array}$ & $\begin{array}{l}-0.076 \\
\pm 0.010\end{array}$ & $\begin{array}{l}-0.066 \\
\pm 0.006\end{array}$ & $\begin{array}{l}-0.072 \\
\pm 0.0 .008\end{array}$ & $\begin{array}{l}-0.069 \\
\pm 0.011\end{array}$ & $\begin{array}{l}-0.064 \\
\pm 0.013\end{array}$ & $\begin{array}{l}-0.059 \\
\pm 0.012\end{array}$ & $\begin{array}{l}-0.059 \\
\pm 0.012\end{array}$ \\
\hline & UTIL & \multicolumn{4}{|c|}{$-5.4 \pm 0.9$} & \multicolumn{3}{|c|}{$-6.6 \pm 1.4$} & 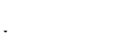 \\
\hline
\end{tabular}

The values represent the mean $\pm \mathrm{SEM}$ of 8 , for glycerol 6 volunteers in $\mathrm{ml} / 100 \mathrm{~g}$ of liver weight $\times \mathrm{min}^{\mathrm{a}}, \mathrm{mmoles}^{\mathrm{b}} \mathrm{l}^{\mathrm{b}}$, and $\mu \mathrm{moles} / 100 \mathrm{~g} \times \mathrm{min}{ }^{\mathrm{c}}$. ${ }^{d}$ Significant difference to basal ( $p<0.05$; paired $\left.t-T e s t\right)$

fatty acids (FFA) $(1.33 \%)$ by a colorimetric method [21]. The samples were placed immediately in ice cold perchloric acid. Pyruvate and acetoacetate were assayed within $6 \mathrm{~h}$ and the other substrates within $48 \mathrm{~h}$.

Hepatic balances were generally calculated from those blood samples collected during the measurement of the hepatic blood flow. From each blood sample determinations of the individual substrates were performed at least in duplicate.

Standard statistical methods have been employed [22] using Student's t-test for paired and unpaired samples when applicable. All the mean values in this paper are given with the standard error of the mean (SEM). 


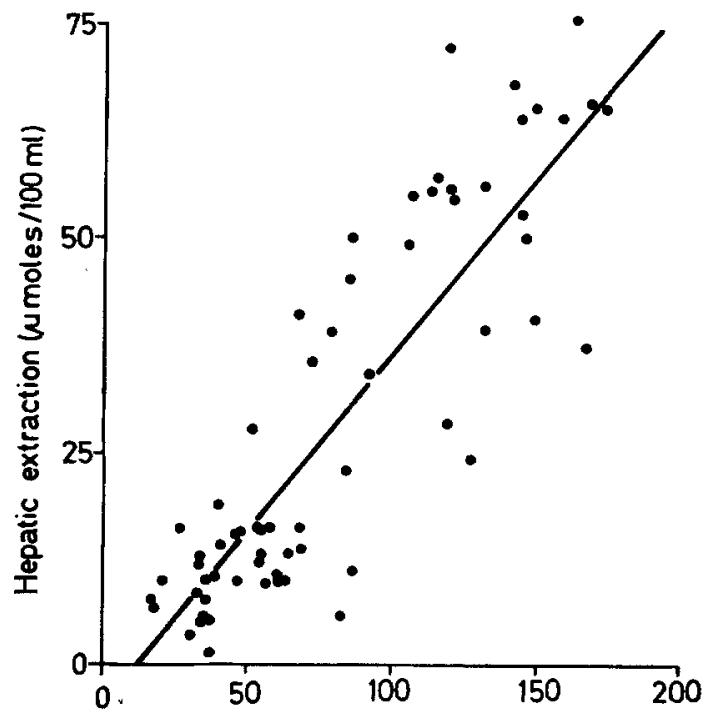

Arterial concentration ( $\mathrm{umoles} / 100 \mathrm{ml}$ )

Fig. 1. Relation between arterial concentration and hepatic extraction of lactate. Each dot represents an individual blood sample. Eight blood samples have been derived from one subject. For details see Materials and Methods. $y=-5.8+0.43 \times ; r=0.86$, $\mathrm{p}<0.005$

\section{Materials}

Lactate was used as a racemate and as a sterile sodium lactate solution containing $150 \mathrm{mM}$ of lactate (Dept. of Pharmacy of Schwabing City Hospital, Munich, FRG). Radioactive ${ }^{133}$ xenon (Radiochemical Center Amersham, Great Britain) was purchased as a sterile solution in $0.9 \%$ sodium chloride $(10 \mathrm{mCi} / \mathrm{ml})$ with a specific activity of $2 \mathrm{Ci} / \mathrm{cm}^{3}$ (NDT).

\section{Results}

Demonstration of identical substrate concentrations in the portal vein and the hepatic artery after an overnight fast (Table 1) indicated that substrate balances derived from arterio-hepatic venous differences represented metabolic rates of the liver. This was also demonstrated in one subject during lactate infusion (W. J., 21. 2. 72).

So as to exclude interference from the catheterization and infusion procedure, the substrates were measured in 9 controls during saline infusion. This procedure revealed no significant changes of substrate concentrations and hepatic substrate balances (Table 2).

Immediately with the start of lactate infusion the arterial lactate level rose almost three-times from 0.44 \pm 0.05 mmoles $/ 1$ up to $1.24 \pm 0.1$ mmoles $/ 1(p<$ 0.005 ) and its arterio-hepatic venous difference fourtimes from a mean in the basal period of $0.12 \pm 0.01$
G. Dietze et al.: Hepatic Substrate Balances during Lactate Infusion

to $0.49 \pm 0.04$ mmoles $/ 1(p<0.005)$ (Table 3$)$. With increasing lactate concentrations hepatic lactate extraction rose continuously (Fig. 1).

Since lactate and pyruvate concentrations suggested a steady state of hepatic lactate and pyruvate metabolism during the 20 and $30 \mathrm{~min}$ after the start of the infusion, and blood flow was measured during this period, this seemed to be the most favourable time to compare the basal balances with those calculated during lactate infusion. As determined by the increased hepatic lactate extraction and the enhanced hepatic blood flow (Table 3 ) the mean value for hepatic lactate uptake rose almost 6 fold from $9.1 \pm 1.2$ up to $51.7 \pm 5.8 \mu$ moles $/ 100 \mathrm{~g} \times \min (\mathrm{p}<0.005)$. Although arterial and hepatic venous pyruvate levels showed a similar rise, its hepatic extraction and utilization remained unchanged (Table 3 ). The concentrations of alanine and glycerol exhibited no significant changes.

Simultaneously with the accelerated lactate uptake the arterio-hepatic venous glucose difference increased from a mean of $-0.54 \pm 0.06$ to -0.84 $\pm 0.07 \mathrm{mmoles} / 1(\mathrm{p}<0.02)$. When adjusted for the faster flow rate, hepatic glucose production was doubled (Table 3). Based on the results from 6 volunteers whose hepatic uptake of all the individual precursors could be registered completely (Table 4), the portion of glucose output which accounted for precursor uptake increased from $11.3 \pm 1.6$ up to $37.3 \pm 3.3$ $\mu$ moles $/ 100 \mathrm{~g} \times \min (\mathrm{p}<0.05)$. That portion of glucose production which was not accountable for by substrate uptake remained constant (Table 4).

Although arterial FFA concentrations did not change significantly there was a significant augmentation of hepatic free fatty acid utilization from a basal value of $8.3 \pm 1.6$ up to $12.6 \pm 2.2 \mu$ moles $/ 100 \mathrm{~g} \times$ min during lactate infusion $(\mathrm{p}<0.05)$ (Table 3$)$. The simultaneously measured total hepatic ketone body ${ }^{2}$ production revealed no significant difference.

Arterial osmolarity $\left(285,291 \mathrm{mosmol} / \mathrm{kg} \mathrm{H}_{2} \mathrm{O}\right)$ and $\mathrm{pH}(7.38,7.40)$ measured in two subjects did not change significantly during lactate infusion $(292,294$ mosmol/ $/ \mathrm{kg} \mathrm{H}_{2} \mathrm{O} ; 7.37,7.38$ ). Heart rates and systolic blood pressures of 4 subjects receiving lactate were unchanged (basal rate: $73.8 \pm 7.1$, basalpressure: 125 $\pm 8.2 \mathrm{mmHg}$; during lactate infusion: $75.8 \pm 6.5$, and $118.8 \pm 10.1 \mathrm{~mm} \mathrm{Hg}$ ).

\section{Discussion}

The aim of this study was to prove whether lactate as a substrate per se would accelerate hepatic

\footnotetext{
2 The term "total ketone bodies" refers to the sum of $\beta 1$-hydroxybutyrate and acetoacetate (Table 2,3 )
} 
Table 4. Hepatic balances of glucose and glucogenic substrates during lactate infusion

\begin{tabular}{|c|c|c|c|c|c|c|c|}
\hline & \multirow[t]{2}{*}{ Glucose } & \multirow{2}{*}{$\begin{array}{l}\text { Calculated rate } \\
\text { of gluconeogenesis }\end{array}$} & \multicolumn{4}{|c|}{ Precursor uptake } & \multirow{2}{*}{$\begin{array}{l}\text { Calculated rate } \\
\text { of glycogenolysis }\end{array}$} \\
\hline & & & Lactate & Pyruvate & Alanine & Glycerol & \\
\hline Basal & $43.1 \pm 2.9$ & $11.3 \pm 1.6$ & $11.9 \pm 1.1$ & $0.9 \pm 0.2$ & $3.1 \pm 1.2$ & $3.6 \pm 0.5$ & $31.8 \pm 3.2$ \\
\hline Lactate & $79.3 \pm 8.3^{b}$ & $37.3 \pm 3.3^{b}$ & $58.9 \pm 5.8$ & $1.1 \pm 0.2$ & $4.6 \pm 1.3$ & $5.4 \pm 0.6^{\mathrm{b}}$ & $42.0 \pm 7.9$ \\
\hline
\end{tabular}

The data represent the mean \pm SEM in $\mu$ moles $/ 100 \mathrm{~g}$ of liver weight $\times$ min. of 6 subjects whose hepatic uptake of individual precursors could be measured simultaneousiy

a These values are indicated in glucose equivalents and hepatic amino acid uptake was estimated as twice that of alanine (24)

b Significant difference to basal $(\mathrm{p}<0.05$; paired $\mathrm{t}$-Test)

gluconeogenesis. This effect could be predicted from experiments on hepatic metabolism with the isolated perfused organ $[1,28]$, with radioactive substrates [25] and with the catheterization technique [2].

Considering that portal and arterial substrate levels were identical (Table 1) hepatic balances have been calculated (Table 2,3) which were in good agreement with those from earlier studies on human splanchnic metabolism $[2,7,23,24,25,26]$. Corresponding to these data, a rate of total hepatic glucose production has been obtained which was found to be 40-50 $\mu$ moles $/ 100 \mathrm{~g} \times \min$ (Table 2, 3, 4). Since one might suppose that in the fasting state the substrates taken up would certainly enter the glucogenic pathway [2], and since the hepatocyte might be expected to synthetize one mole of glucose from two moles of these precursors [28], the portion of glucose output which can be accounted for by gluconeogenesis could be estimated from precursor uptake. As presented in table 4 this portion was about $25 \%$ and the residual portion ought to be due to glycogenolysis. These findings were in good accord with results derived from isotope studies [25] as well as from balance studies [2] and from serial determinations of the hepatic glycogen content [29].

The recorded data concerning FFA and ketone body metabolism (Table 2,3) were also in good agreement with those in the literature [23, 27]. Since esterification and biosynthesis had been shown to account only for 20-30 per cent of hepatic FFA extraction in the postabsorptive state [23] and had been reduced further during fasting [30] one might consider the portion of FFA which accounted for hepatic ketone body production to be about $20-40$ per cent $[23,27]$. The relatively large free fatty acid uptake [23] led to the suggestion that FFA may be the prime substrate of the livers oxidative metabolism [30]. This suggestion was strengthened by the fact that its respiratory quotient was found to be $0.65[23,25]$. According to data from earlier studies about $40-60 \%$ of FFA could be supposed to be completely oxidized to provide hepatic energy demand.

During lactate infusion arterial pyruvate and lac- tate concentrations rose two- and threefold, respectively (Table 3 ), corresponding to concentrations caused by moderate muscular exercise [2]. The residual substrates did not change. Since the arterial and portal concentrations exhibited no essential differences (single observation) the balances registered during lactate infusion have also been considered to represent metabolic rates of the liver. Since the carbohydrate metabolism of the controls did not reveal effects from the catheterization and infusion procedure (Table 2), the hepatic rates registered during lactate infusion needed no revision. Accordingly, as could be expected from in vitro studies $[1,28]$, an almost sixfold increase of hepatic lactate uptake was registered. This was partly due to lactate extraction, which rose continuously with increasing serum lactate levels (Fig. 1). This phenomenon had also been observed in the isolated perfused liver [1] and had been explained by the fact that no step in the glucogenic pathway was near saturation at physiological substrate concentrations. In contrast to the in vitro situation [1], the fivefold increase of lactate uptake was also due to a faster flow rate. This effect on hepatic blood flow had also been observed in the dog and had been supposed to be due to changes of serum osmolarity or serum-pH caused by the lactate load [31]. However, this could not be the cause, since in two subjects both these variables remained reasonably constant (see Results). Furthermore, hormones especially catecholamines were also unlikely to be involved, since there was no evidence for an enhancement of lipolysis (Table 3), heart rate or blood pressure (see Results). Adenosine derived from increased break down of energy rich phosphates, has been suggested to be one of the factors controlling organ blood flow [32]. This hypothesis could also turn out to be true for the liver, since acceleration of gluconeogenesis was found to increase hepatic energy demand $[28,1]$ and activation of hepatic metabolism was found to accelerate perfusion [33].

In accordance with the findings from the isolated perfused organ [1], the fivefold increase of hepatic lactate uptake was associated with a doubling of hepatic glucose formation (Table 3,4). Corresponding to 
the recorded precursor uptake this increase of hepatic glucose output was almost entirely due to an enhanced gluconeogenesis from lactate. The portion which was not accountable for by precursor uptake showed no significant change (Table 4). This was in good agreement with the finding that the hepatic glycogen content did not change [31].

This acceleration of hepatic gluconeogenesis from lactate was accompanied by an enhancement of the hepatic FFA uptake (Table 3). Since the hepatic ketone body production did not rise correspondingly there was evidence for impaired ketogenesis. This finding could be presumed to be in good accord with the well-known antiketogenic effect of lactate $[30,34]$ which had been interpreted to be largely due to faster esterification and only to a minor degree due to accelerated citric acid cycle activity [34]. That both these mechanisms might also play a role in the in vivo situation was emphasized by increased hepatic glycerol uptake (Table 3,4) and carbon dioxide production during lactate infusion [31]. Since the hepatic precursor uptake corresponded almost exactly with the acceleration of hepatic glucose output ([34], Table 4), the larger $\mathrm{CO}_{2}$ release could be presumed to stem rather from the increased FFA uptake. These findings were consistent with the present view that hepatic energy requirements required for accelerated gluconeogenesis might be covered from the oxidation of FFA [1, 23, 35]. This hypothesis had also been underlined by in vitro studies with radioactive labelled oleate which showed significant hepatic release of labelled carbon dioxide during lactate induced stimulation of hepatic gluconeogenesis [34]. It would not be in contrast to the data from earlier studies [36] which revealed smaller oxaloacetate content and consequently reduced citric acid cycle activity during acceleration of gluconeogenesis. These findings had only been observed during ketosis due to enhanced lipolysis e. g. during fasting and diabetic acidosis.

Acknowledgements. We are indebted to Ing. E. A. Bauer, Mrs. E. Müller and G. Bauer and Miss J. Strigel for expert technical assistance. We thank Prof. Dr. G. Löffler for the determination of insulin. Thanks are also due to Dr. M. A. Schmidt, Dr. A. Wilhelm, Dr. M. Henkel and Dr. T. Flaschenträger from the Dept. of Surgery for their cooperation concerning the catheterization of the umbilical vein. We are grateful to Dr. E. Jörn for statistical mathematics and to the Leibnitz-Rechen-Zentrum, Bavarian Academy of Sciences, for good cooperation.

\section{References}

1. Exton, J. H., Park, C. R.: Control of gluconeogenesis in liver. I. General features of gluconeogenesis in the perfused livers of rats. J. biol. Chem. 242, 2622-2636 (1967)
2. Wahren, J., Felig, P., Ahlberg, G., Jorfeldt, L.: Glucose metabolism during leg exercise in man. J. clin. Invest. 50, 2715 -1725 (1971)

3. Statist. Bull. Metrop. Life Insur. Co. 40, Nov.-Dez. (1959)

4. Carbalhaes, O. G.: Portography. A preliminary report of a new technique via the umbilical vein. Clin. Proc. Child. Hosp. (Wash.) 15, 120-125 (1959)

5. Boberg, J.: Heparin-released blood plasma lipoprotein lipase activity in patients with hyperlipoproteinemia. Acta med. scand. 191, 97-105 (1972)

6. Sambhi, M. P:: Hepatic vein catheterization. In: Intravascular catheterization (ed. H. A. Zimmermann), pp. 1024-1056. Springfield: C. C. Thomas 1966

7. Tygstrup, N., Winkler, R., Lundquist, F.: The mechanism of the fructose effect on the ethanol metabolism of the human liver. J. clin. Invest. 44, 817-830 (1964)

8. Veall, N., Mallett, B. L.: Regional cerebral blood flow determination by ${ }^{133}$ xenon-inhalation and external recording: The effect of arterial recirculation. Clin. Sci. 30, 353-369 (1966)

9. Schmitz-Feuerhake, I., Tägder, K., Fröhlich, H., Pixberg, H. U., Haubold, E.: 9the Ann. Meet. Soc. Nucl. Med., Antwerpen, 1971. Die Bestimmung der spezifischen Durchblutung von Leber, Milz und Niere durch Inhalation von radioaktivem Xenon. In: Nuklearmedizin (Hrsg. P. M. van Vaerenbergh, H. W. Pabst, G. Hör), S. 264-268. New York: Schattauer Verlag 1973

10. Dietze, G., Wicklmayr, M., Czempiel, H., Heftling, H. G., Mehnert, H.: On the analysis of the hepatic-venous ${ }^{133}$ xenonclearance after the application of the gas by inhalation. Klin. Wschr. 53, 638-640 (1975)

11. Kety, S.: The theory and applications of the exchange of inert gas at the lungs and other tissues. Pharmacol. Rev. 3, 1-26 (1951)

12. Morales, M. F., Smith, R. E.: The physiological factors which govern inert gas exchange. Bull. Math. Biophys. 7, 99-106 (1945)

13. Andersen, A. M., Lodefoged, J.: Partition coefficient of ${ }^{133}$ xenon between various tissues and blood in vivo. Scand. J. clin. Lab. Invest., 19, 72-78 (1967)

14. Bergmeyer, H. U., Bernt, E., Schmidt, F., Stork, H.: D-Glucose, Bestimmung mit Hexokinase und Glucose-6-phosphatDehydrogenase. In: Methoden der enzymatischen Analyse, Band II, S. 1163-1172. Weinheim: Verlag Chemie 1970

15. Hohorst, H. J.: L-(+)-Lactat. In: Methoden der enzymatischen Analyse, Band II (Hrsg. H. U. Bergmeyer), S. 1425-1429. Weinheim: Verlag Chemie 1970

16. Czok, R., Lamprecht, W.: Pyruvat, Phosphoenolpyruvat und D-Glycerat-2-phosphat. In: Methoden der enzymatischen Analyse, Band II (Hrsg. H. U. Bergmeyer), S. 1407-1411. Weinheim: Verlag Chemie 1970

17. Williamson, D. H.: L-Alanin. In: Methoden der enzymatischen Analyse, Band II (Hrsg. H. U. Bergmeyer), S. 1634-1637. Weinheim: Verlag Chemie 1970

18. Williamson, D. H., Mellanby, J.: $\beta$-Hydroxybutyrat. In: Methoden der enzymatischen Analyse, Band II (Hrsg. H. U. Bergmeyer), S. 1772-1775. Weinheim: Verlag Chemie 1970

19. Eggstein, M., Kreutz, F. H.: Eine neue Bestimmung der Neutralfette im Blutserum und Gewebe. Klin. Wschr. 44, 262-276 (1966)

20. Mellanby, J., Williamson, D. H.: Acetacetat. In: Methoden der enzymatischen Analyse, Band II (Hrsg: H. U. Bergmeyer), S. 1776-1779. Weinheim: Verlag Chemie 1970

21. Duncombe, W. G.: The colorimetric microdetermination of long-chain fatty acids. Biochem. J. 88, 7-18 (1963)

22. Snedecor, G. W., Cochran, W. G.: Statistical methods. 6th edition. Ames, Iowa: Iowa State University Press 1967

23. Havel, R. J., Rane, J. P., Balasse, E. O., Segel, N., Bano, L. V.: Splanchnic metabolism of free fatty acids and production of 
triglycerides of very low density lipoproteins in normotriglyceridemic and hypertriglyceridemic humans. J. clin. Invest. 49, 2017-2035 (1970)

24. Owen, O. E., Felig, P., Morgan, A. P., Wahren, J., Cahill, G. F., Jr.: Liver and kidney metabolism during prolonged starvation. J. clin. Invest. 48, 574-583 (1969)

25. Kreisberg, R. A., Pennington, L. F., Boshell, B. R.: Lactate turnover and gluconeogenesis in normal and obese humans. Diabetes 19, 53-62 (1970)

26. Myers, J. D.: Net splanchnic glucose production in normal man and in various dissease states. J. clin. Invest. 29, 1421-1434 (1950)

27. Hagenfeldt, L., Wahren, J., Pernow, B., Räf, L.: Uptake of individual free fatty acids by skeletal muscle and liver in man. J. clin. Invest. 51, 2324-2330 (1972)

28. Scholz, R., Zehner, J., Bücher, T.: Gluconeogenese in der hämoglobinfrei perfundierten Rattenleber. Acta hepatosplenol. (Stuttg.) 13, 376-381 (1966)

29. Hultman, E., Nilsson, L. H.: Liver glycogen in man. In: Muscle metabolism during exercise. (eds. B. Pernow, B. Saltin), pp. 143-151. New York: Plenum Press 1971

30. McGarry, J. D., Foster, D. W.: Regulation of ketogenesis and clinical aspects of the ketotic state. Metabolism 21, 471-489 (1972)

31. Kramer, K., Driessen, G., Brechtelsbauer, H.: Lactate elimina- tion and $\mathrm{O}_{2}$-consumption of the liver in narcotized dogs. Pflügers Arch. ges. Physiol. 330, 195-202 (1971)

32. Berne, R. M., Rubio, R., Dobson, J. G., Jr., Curnish, R. R.: Adenosine adenine nucleotides as possible mediators of cardiac and skeletal muscle blood flow regulation. Circulat. Res. 28 (Suppl. 1), 115-132 (1971)

33. Scholtholt, J.: Das Verhalten der Durchblutung der Leber bei Steigerung des Sauerstoffverbrauches der Leber. Pflügers Arch. ges. Physiol. 318, 202-211 (1970)

34. McGarry, J. D., Foster, D. W.: The regulation of ketogenesis from oleic acid and the influence of antiketogenic agents. J. biol. Chem. 25, 6247-6253 (1971)

35. Wicland, O.: Ketogenesis and its regulation. Advanc. Metab. Dis. 3, 1-47 (1968)

36. Krebs, H. A.: The regulation of the release of ketone bodies by the liver. Advanc. Enzymol. Regulat. 4, 339-353 (1966)

Received: March 6, 1976, and in revised form: July 16, 1976

Dr. G. Dietze

Forschergruppe Diabetes

Schwabinger-Krankenhaus

Kölner Platz 1

D-8000 München 40

Federal Republic of Germany 